\title{
Activation-Induced Expression of CD56 by T Cells Is Associated With a Reprogramming of Cytolytic Activity and Cytokine Secretion Profile In Vitro
}

\author{
Jane Kelly-Rogers, Laura Madrigal-Estebas, \\ Tony O’Connor, and Derek G. Doherty
}

\begin{abstract}
A subset of human $\mathrm{T}$ lymphocytes expresses the natural killer (NK) cell-associated receptor CD56 and is capable of major histocompatibility complex (MHC)- unrestricted cytotoxicity against a variety of autologous and allogeneic tumor cells. $\mathrm{CD}_{5} 6^{+} \mathrm{T}$ cells have shown potential for immunotherapy as antitumor cytotoxic effectors, but their capacity to control adaptive immune responses via cytokine secretion is unclear. We have examined the inducibility of $\mathrm{CD}_{5} 6^{+} \mathrm{T}$ cells from human blood in vitro and compared the kinetics of Th1, Th2, and regulatory cytokine secretion by $\mathrm{CD} 56^{+} \mathrm{T}$ cells with those of conventional $\mathrm{CD}^{-} 6^{-} \mathrm{T}$ cells. CD 56 was induced on $\mathrm{CD}^{+}$and $\mathrm{CD} 4^{-} \mathrm{CD}^{-} \mathrm{T}$ cells by $\mathrm{CD} 3 / \mathrm{T}$-cell receptor (TCR)-mediated activation, particularly when grown in the presence of interleukin (IL)-2. Activationinduced $\mathrm{CD}^{+} 6^{+} \mathrm{T}$ cells proliferated less vigorously but
\end{abstract}

$\begin{array}{ll}\text { ABBREVIATIONS } \\ \text { IFN } & \text { interferon } \\ \text { IL } & \text { interleukin } \\ \text { mAb } & \text { monoclonal antibody } \\ \text { MHC } & \text { major histocompatibility complex } \\ \text { NK } & \text { natural killer } \\ \text { NKR } & \text { natural killer cell receptor }\end{array}$

\section{INTRODUCTION}

A subset of human $\mathrm{T}$ lymphocytes expresses the cellsurface, immunoglobulin superfamily molecule, CD56, which is typically expressed by natural killer (NK)

From the Lymphocyte Biology Group, Institute of Immunology and Department of Biology, The National University of Ireland Maynooth, Maynooth, County Kildare, Ireland.

Address reprint requests to: Dr. Derek G. Doherty, Institute of Immunology and Department of Biology, National University of Ireland, Maynooth, Maynooth, Co., Kildare, Ireland: Tel: 353-1-7083856; Fax: 3531-7083845; E-mail: derek.g.doherty@nuim.ie

Received May 31, 2006; revised July 15, 2006; accepted August 17, 2006

Human Immunology 67, 863-873 (2006)

(c) American Society for Histocompatibility and Immunogenetics, 2006

Published by Elsevier Inc. displayed enhanced natural cytotoxicity compared with CD56 ${ }^{-} \mathrm{T}$ cells. $\mathrm{CD} 56^{+} \mathrm{T}$ cells released interferon- $\gamma$ (IFN- $\gamma$ ) and interleukin-13 (IL-13), but not IL-10, upon TCR stimulation. Flow cytometric analysis demonstrated that, compared with $\mathrm{CD} 6^{-} \mathrm{T}$ cells, elevated proportions of $\mathrm{CD} 56^{+} \mathrm{T}$ cells expressed IFN- $\gamma$, IL-4, and IL-13 within hours of activation. These acquired cytolytic and cytokine secretion activities of $\mathrm{CD}_{5} 6^{+} \mathrm{T}$ cells make them potential targets for immunotherapy for infectious and immune-mediated disease. Human Immunology 67, 863-873 (2006). (C) American Society for Histocompatibility and Immunogenetics, 2006. Published by Elsevier Inc.

KEYWORDS: CD $56^{+}$T cells; natural killer cells; cytokines; cytotoxicity; kinetics

$\begin{array}{ll}\text { NKT } & \text { natural killer T } \\ \text { PBMC } & \text { peripheral blood mononuclear cell } \\ \text { PHA } & \text { phytohemagglutinin } \\ \text { PMA } & \text { phorbol myristate acetate } \\ \text { TCR } & \text { T-cell receptor }\end{array}$

cells, neurons, and some tumor cells $[1,2] . \mathrm{CD} 56^{+} \mathrm{T}$ cells are heterogenous in nature and include $\mathrm{CD} 4^{+}$, $\mathrm{CD} 8{ }^{+}$, and $\mathrm{CD}^{-} \mathrm{CD} 8^{-}$cells expressing $\alpha \beta$ or $\gamma \delta$ major histocompatibility complex (MHC) or CD1drestricted $\mathrm{T}$-cell receptors (TCRs), and various combinations of NK cell receptors (NKRs), including CD16, CD56, CD94/NKG2, CD161, NKG2D, and killer immunoglobulinlike receptors [3-5]. They generally account for less that $5 \%$ of peripheral blood $\mathrm{T}$ cells and up to $50 \%$ of $\mathrm{T}$ cells in the liver $[6,7]$ and in the intestine $[8-10]$. Functionally, $\mathrm{CD} 56^{+} \mathrm{T}$ cells display properties of both NK cells and $\mathrm{T}$ cells. They are

0198-8859/06/\$-see front matter doi:10.1016/j.humimm.2006.08.292 
capable of potent perforin/granzyme-mediated killing of a variety of tumor target cells in vitro and in vivo [3, 11, 12]. This MHC-unrestricted cytotoxicity does not require prior antigenic exposure but appears to involve the ligation of stimulatory NKRs and/or the TCR, and exposure to cytokines of diverse cellular origins, including interferon- $\gamma$ (IFN- $\gamma$ ), interleukin-1 (IL-1) and IL-2 [11], IFN- $\alpha$, IL-2, IL-12 and/or IL-18 [13], IL-2 and IL-12 [13-17], and IL-15 [4]. The cytotoxic activities of $\mathrm{CD} 6^{+} \mathrm{T}$ cells against autologous and allogeneic leukemic cells are reported to be superior to those of NK cells and lymphokine activated killer cells $[11,18,19]$, and phase I trials for leukemia by using autologous $\mathrm{CD} 56^{+} \mathrm{T}$ cells generated ex vivo by $\mathrm{CD} 3$ stimulation of peripheral blood mononuclear cells (PB$\mathrm{MCs}$ ) in the presence of cytokines (cytokine-induced killer cells) are under way [19-22].

In addition to NK-like cytotoxicity, $\mathrm{CD} 56^{+} \mathrm{T}$ cells are capable of TCR-mediated and MHC- or CD1drestricted cytotoxicity and secretion of cytokines, including IFN- $\gamma$, TNF- $\alpha$, and IL- 4 , which promote Th1 or Th2 adaptive immune responses $[3-5,13,15,23-$ $25]$. The dual innate and adaptive immune functions place $\mathrm{CD} 56^{+} \mathrm{T}$ cells alongside natural killer $\mathrm{T}(\mathrm{NKT})$ cells and subsets of $\gamma \delta \mathrm{T}$ cells as frontline innate immune effectors and potential regulators of adaptive immune responses against microorganisms and tumors $[26,27]$. These properties make $\mathrm{CD} 56^{+} \mathrm{T}$ cells attractive potential targets for therapy for infectious and immune-mediated diseases as well as cancer. In support of this notion, numerical and functional deficiencies and phenotypic alterations of $\operatorname{CD} 56^{+} \mathrm{T}$ cells have been reported in patients with various infectious and autoimmune diseases and cancer [23, 28-32].

In the present study, we have investigated the potential of human $\operatorname{CD5} 6^{+} \mathrm{T}$ cells as initiators and regulators of adaptive immune responses by examining the kinetics of their inducibility from human blood in vitro and comparing their functional properties with those of conventional $\mathrm{CD} 56^{-} \mathrm{T}$ cells. We demonstrate that $\mathrm{CD} 56$ expression can be induced on $\mathrm{CD}_{5} 6^{-} \mathrm{T}$ cells by CD3/TCR-mediated activation and that activation-induced $\mathrm{CD} 6^{+} \mathrm{T}$ cells display MHCunrestricted killing of target cells and IFN- $\gamma$ and IL13 , but not IL-10 secretion. Flow cytometric analysis demonstrated that $\mathrm{CD} 6^{+} \mathrm{T}$ cells more frequently expressed IFN- $\gamma$, IL- 4 , and IL- 13 than $\mathrm{CD} 56^{-} \mathrm{T}$ cells in the first 24 hours following stimulation. Thus, in addition to acquiring innate cytolytic activities, the induction of CD56 on T cells is frequently associated with enhanced capacity to stimulate and polarize adaptive immune responses.

\section{MATERIALS AND METHODS}

\section{Subjects}

Blood samples were obtained from healthy donors. PBMCs were prepared by standard Lymphoprep (Nycomed, Oslo, Norway) density gradient centrifugation. Ethical approval for this study was obtained from the Ethics Committee of the National University of Ireland, Maynooth.

\section{Antibodies and Flow Cytometry}

Monoclonal antibodies ( $\mathrm{mAb}$ ) specific for human $\mathrm{CD} 3$, CD4, CD8 $\alpha \beta$, CD 56, $\gamma \delta$ TCR, $\alpha \beta T C R, C D 161$, CD69, HLA-DR, CD25, CD45RO, the invariant $\mathrm{V} \alpha 24 \mathrm{~J} \alpha 18$ TCR $\alpha$-chain found on CD1d-restricted NKT cells $[24,27]$ (6B11), IFN- $\gamma$, IL-4, IL-5, IL-10, and IL-13 were obtained from BD-Pharmingen (Oxford, UK). The expression of cell surface or intracellular antigens by fresh or cultured PBMCs or purified PBMC subsets was detected by $\mathrm{mAb}$ staining and four-color flow cytometry (FACSCalibur, Becton Dickinson, Oxford, UK) with CellQuest software (Becton Dickinson).

\section{In Vitro Stimulation and Expansion of T Cells}

PBMCs or enriched PBMC subsets were suspended in complete RPMI medium (RPMI 1640 containing 25 $\mathrm{mM}$ HEPES, $2 \mathrm{mM}$ L-glutamine, $50 \mu \mathrm{g} / \mathrm{ml}$ streptomycin, $50 \mathrm{U} / \mathrm{ml}$ penicillin, and $10 \%$ fetal calf serum) at a density of $0.5 \times 10^{6}$ cells $/ \mathrm{ml}$ and stimulated for up to 120 hours with either $10 \mathrm{ng} / \mathrm{ml}$ phorbol myristate acetate (PMA) plus $1 \mu \mathrm{g} / \mathrm{ml}$ ionomycin, or with anti-CD3 $\mathrm{mAb}(0-3 \mu \mathrm{g} / \mathrm{ml}$ HIT3a; BD-Pharmingen Erembadege, Belgium) that was bound to microwell plates by incubation at $37^{\circ} \mathrm{C}$ for 4 hours in $0.1 \mathrm{M} \mathrm{Na}_{2} \mathrm{HPO}_{4}, \mathrm{pH} 9$. For longer-term stimulation and expansion of $\mathrm{T}$ cells, PBMCs were suspended in complete RPMI medium containing $5 \mu \mathrm{g} / \mathrm{ml}$ phytohemagglutinin (PHA, SigmaAldrich, Dublin, Ireland), and $25 \mathrm{ng} / \mathrm{ml} \mathrm{recombinant}$ human IL-2 (National Cancer Institute, Frederick, Maryland) was added 2 days later and at 4-5 day intervals thereafter. After 12-14 days, the cells were restimulated with PHA and an equal number of irradiated (5000 rad) allogeneic PBMCs and fed with IL-2 as above. The cultures were analyzed by flow cytometry or separated into $\mathrm{CD} 56^{+}$and $\mathrm{CD} 56^{-}$subsets on day 28.

\section{Purification of $\mathrm{CD} 56^{+}$and $\mathrm{CD} 56^{-} \mathrm{T}$ Cells}

$\mathrm{CD} 56^{+}$and $\mathrm{CD} 56^{-} \mathrm{T}$ cells were purified from fresh PBMCs or PBMCs that were stimulated twice with PHA and cultured with IL-2, as described above, which resulted in the death of all non-T $\left(\mathrm{CD}^{-}{ }^{-}\right)$cells and selective expansion of $\mathrm{CD} 6^{+} \mathrm{T}$ cells (see results). $\mathrm{CD} 56^{+}$ and $\mathrm{CD} 56^{-}$cells were then purified using $\mathrm{CD} 56 \mathrm{mi}-$ crobeads (Miltenyi Biotec, Gladbach Bergische, Germany). The purities of enriched fractions were deter- 
mined by flow cytometry, and only preparations that yielded purities of $>98 \%$ were used in functional studies.

\section{Cytotoxicity Assays}

MHC-unrestricted cytotoxicity by $\mathrm{CD} 56^{+}$and $\mathrm{CD} 56^{-}$ $\mathrm{T}$ cells, purified as above, was assayed in 4-hour ${ }^{51}$ chromium-release assays [25] using K562 cells as targets.

\section{Analysis of Cytokine Production}

The release of IFN- $\gamma$, IL-13, and IL-10 into supernatants of stimulated cells $\left(0.5 \times 10^{6} / \mathrm{ml}\right)$ over 3 days was quantified by enzyme linked immunosorbent assay (ELISA) by using antibody pairs and recombinant cytokine standards purchased from R\&D Systems (Abingdon, UK).

Intracellular expression of IFN- $\gamma$, IL-4, IL-5, IL-10, and IL-13 by PBMC subsets was detected by flow cytometry after stimulating the cells with PMA and ionomycin or anti-CD3 $\mathrm{mAb}$ in the presence of brefeldin $\mathrm{A}$ $(10 \mu \mathrm{g} / \mathrm{ml}$, Sigma-Aldrich), an inhibitor of protein translocation from the endoplasmic reticulum to the Golgi apparatus. Cells were then stained with $\mathrm{mAbs}$ specific for surface $\mathrm{CD} 3$ and $\mathrm{CD} 56$, fixed with $4 \%$ paraformaldehyde, and permeabilized with $0.2 \%$ saponin (SigmaAldrich) before adding the anti-cytokine mAbs [25]. As controls, unstimulated cells were treated similarly.

\section{Statistical Analysis}

Mean frequencies of lymphocyte subsets and mean cytokine levels were compared using the paired Student's $t$ test and $p$ values of $<0.05$ were considered significant.

\section{RESULTS}

\section{CD56 Expression}

\section{by $\mathrm{T}$ Cells Is Induced by Activation}

Flow cytometric analysis of freshly isolated PBMCs (Figure $1 \mathrm{~A}$ ) from 33 healthy donors indicated that $\mathrm{CD} 56$ was expressed by $0.7 \%-14.2 \%$ (mean $5 \%$ ) of $\mathrm{CD}^{+}$cells. $\mathrm{Up}$ to $6.9 \%$ (mean $1.9 \%$ ) of $\mathrm{CD} 56^{+} \mathrm{T}$ cells, compared with $9.5 \%$ (range $1.7 \%-24.7 \%$ ) of NK cells, expressed high levels of $\operatorname{CD} 56\left(\mathrm{CD} 56^{\text {bright }}\right.$ cells). About $50 \%$ (range $17.6 \%-80 \%)$ of $\mathrm{CD} 56^{+} \mathrm{T}$ cells expressed the CD8 coreceptor, whereas the remainder expressed $\mathrm{CD} 4$ or double-negative $\mathrm{CD}^{-} \mathrm{CD}^{-}$phenotypes in approximately equal proportions. Of the $\mathrm{CD}^{2} 6^{+} \mathrm{T}$ cells, $14.4 \%$ (range 9.3\%-27.9\%) had $\gamma \delta$ TCRs, compared with $2.6 \%$ of $\mathrm{CD}^{-} 6^{-} \mathrm{T}$ cells. A higher proportion $(1.6 \%)$ of $\mathrm{CD}^{+} 6^{+} \mathrm{T}$ cells (range $0.6 \%-2.5 \%$ ) had invariant $\mathrm{V} \alpha 24 \mathrm{~J} \alpha 18$ TCR chains compared with $0.02 \%$ of CD56 ${ }^{-} \mathrm{T}$ cells $(0.007 \%-0.03 \%$, Table 1 and data not shown).
A

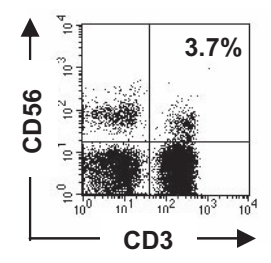

B

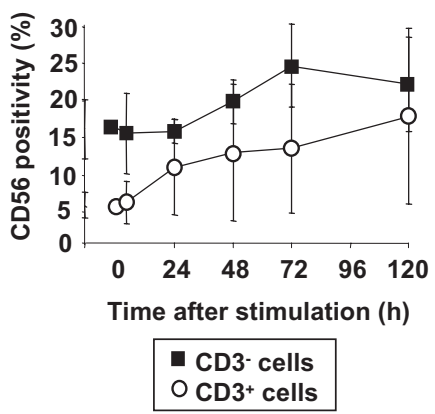

C

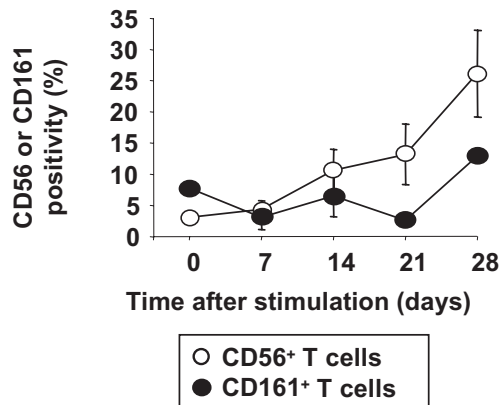

D

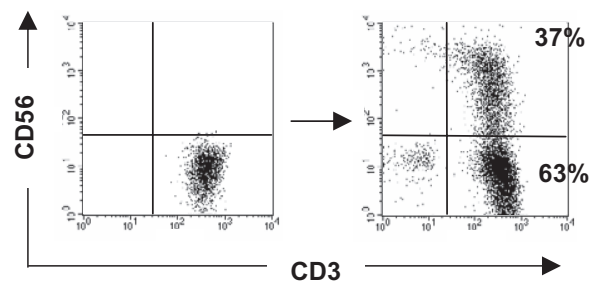

FIGURE 1 CD56 is induced on peripheral blood $\mathrm{T}$ cells by activation in vitro. (A) Representative flow cytometric dot plot demonstrating the expression of $\mathrm{CD} 56$ by $\mathrm{CD}^{+}$and $\mathrm{CD} 3^{-}$ lymphocytes in fresh peripheral blood mononuclear cells (PBMCs). (B) Kinetics of CD56 positivity of $\mathrm{CD}^{+}$and $\mathrm{CD}^{-}$ PBMCs after stimulation with $0.3 \mu \mathrm{g} / \mathrm{ml}$ plate-bound antiCD3 monoclonal antibody (means of 9 samples). (C) Kinetics of CD56 and CD161 expression by peripheral T cells after stimulation with phytohemagglutinin and culture with interleukin (IL)-2 (means of three samples). (D) Representative flow cytometric dot plots illustrating expression of CD56 by T cells before (left) and after (right) expansion for 28 days with phytohemagglutinin and IL-2 when PBMCs that were depleted of $\mathrm{CD} 56^{+} \mathrm{T}$ cells were used as starting material. Error bars illustrate standard errors of the means.

The inducibility and stability of CD56 expression by $T$ cells was examined by stimulating PBMCs with platebound anti-CD3 $\mathrm{mAb}$ and analyzing $\mathrm{CD} 56$ expression by $\mathrm{CD}^{+}$cells at intervals up to 120 hours. Figure $1 \mathrm{~B}$ illustrates that short-term (5-day) $\mathrm{T}$-cell activation with anti-CD $3 \mathrm{mAb}$ alone resulted in a gradual increase in the percentages of $\mathrm{T}$ cells that expressed $\mathrm{CD} 56$, from 6\%$17.9 \%$ (threefold, means of nine samples). No expansion 
TABLE 1 Phenotypic properties of freshly isolated human peripheral blood CD $56^{+} \mathrm{T}$ cells and $\mathrm{CD} 56^{+} \mathrm{T}$ cells induced by two rounds of stimulation with PHA and culture with IL-2 ${ }^{\mathrm{a}}$

\begin{tabular}{|c|c|c|}
\hline Cell-surface phenotype & Percent of fresh $\mathrm{CD} 56^{+} \mathrm{T}$ cells (mean and range) & $\begin{array}{l}\text { Percent of activation-induced } \mathrm{CD} 56^{+} \mathrm{T} \text { cells } \\
\text { (mean and range) }\end{array}$ \\
\hline $\mathrm{CD} 4^{+} \mathrm{CD} 8^{-}$ & $23(7-41)$ & $0.6(0-1.5)$ \\
\hline $\mathrm{CD}^{+} \mathrm{CD}^{-}$ & $52(18-80)$ & $74(61-88)$ \\
\hline $\mathrm{CD}^{-} \mathrm{CD}^{-}$ & $15(10-34)$ & $25.9(12-40)$ \\
\hline $\mathrm{CD} 4^{+} \mathrm{CD} 8^{+}$ & $0.6(0-1.0)$ & $0.3(0-0.9)$ \\
\hline$\alpha \beta \mathrm{TCR}$ & $86(72-91)$ & $96(93-98)$ \\
\hline$\gamma \delta \mathrm{TCR}$ & $14(9.3-28)$ & $4(1.7-7.4)$ \\
\hline $\mathrm{V} \alpha 24 \mathrm{~J} \alpha 18 \mathrm{TCR}$ & $1.6(0.6-2.5)$ & $2(1.3-2.7)$ \\
\hline
\end{tabular}

Abbreviations $\mathrm{PHA}=$ phytohemagglutinin; $\mathrm{IL}=$ interleukin.

${ }^{\text {a }}$ Data are means and ranges of 4-15 samples.

of overall cell numbers was observed. After repeated stimulation with PHA and culturing with IL-2, total cell numbers increased by a mean factor of 4.2 , and the mean frequencies of $\mathrm{CD}^{2} 6^{+} \mathrm{T}$ cells rose from $3 \%-26.2 \%$ (ninefold), whereas the frequencies of $\mathrm{T}$ cells expressing another NKR, CD161, remained constant (means of three samples, Figure 1C). This amounts to a mean

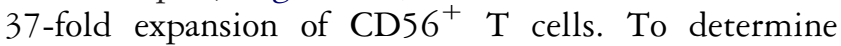
whether these expansions of $\mathrm{CD} 56^{+} \mathrm{T}$ cells are a result of the induction of $\mathrm{CD} 56$ expression by activated $\mathrm{CD} 56^{-} \mathrm{T}$ cells or the selective expansion of $\mathrm{CD} 56^{+} \mathrm{T}$ cells, PBMCs were depleted of $\operatorname{CD} 56^{+} \mathrm{T}$ cells by using mAb-coated magnetic beads and were expanded with PHA and IL-2. After 28 days, CD56 was expressed by a mean of $37 \%$ of $\mathrm{T}$ cells, where purified $\mathrm{CD} 56^{-} \mathrm{T}$ cells were used as starting material (Figure 1D). These results provide evidence that $\operatorname{CD} 56$ can be induced on $\mathrm{T}$ cells by activation.

\section{Phenotypes of Activation-Induced $\mathrm{CD}_{5} 6^{+} \mathrm{T}$ Cells} $\mathrm{CD} 56^{+} \mathrm{T}$ cells were expanded from PBMCs by subjecting them to two rounds of stimulation with PHA and culturing them with IL-2. Flow cytometry was used to compare the frequencies of CD4, CD8 and $\alpha \beta, \gamma \delta$ and V $\alpha 24 \mathrm{~J} \alpha 18$ TCR expression by activation-induced $\mathrm{CD} 56^{+} \mathrm{T}$ cells with those of $\mathrm{CD} 56^{+} \mathrm{T}$ cells in fresh blood. Table 1 demonstrates that, whereas a mean of $23 \%$ of $\mathrm{CD}^{2} 6^{+} \mathrm{T}$ cells in fresh blood express $\mathrm{CD} 4$, this coreceptor was not present on activation-induced $\mathrm{CD} 56^{+}$ $\mathrm{T}$ cells, all of which expressed $\mathrm{CD}^{+}$(mean $74 \%$ ) or double-negative $\mathrm{CD}^{-} \mathrm{CD}^{-}$(26\%) phenotypes. Activation-induced expansion of $\mathrm{CD} 56^{+} \mathrm{T}$ cells was not associated with expansions of $\gamma \delta \mathrm{T}$ cells, which accounted for $14 \%$ of $\mathrm{CD} 6^{+} \mathrm{T}$ cells in fresh blood compared with $4 \%$ of induced $\mathrm{CD} 56^{+} \mathrm{T}$ cells. In contrast, CD1d-restricted NKT cells expressing invariant V $\alpha 24 \mathrm{~J} \alpha 18$ TCRs and CD56 were expanded by activation, these TCR chains being present on $2 \%$ of induced
$\mathrm{CD} 6^{+} \mathrm{T}$ cells and $1.6 \%$ of $\mathrm{CD} 56^{+} \mathrm{T}$ cells from fresh blood (Table 1).

\section{CD $56^{+}$T Cells Display Reduced Proliferative Capacity and Enhanced MHC-Unrestricted Cytotoxicity Compared With CD56 ${ }^{-}$T Cells}

$\mathrm{CD} 56^{+}$and $\mathrm{CD} 56^{-} \mathrm{T}$ cells were purified from freshly isolated PBMCs, and $5 \times 10^{6}$ cells of each type were expanded for 28 days with PHA and IL-2, as described above. At various time intervals, the number of viable cells was determined. Figure $2 \mathrm{~A}$ illustrates that purified CD $56^{-} \mathrm{T}$ cells underwent a mean 17-fold expansion, whereas $\mathrm{CD} 6^{+} \mathrm{T}$ cells expanded about fourfold in this time, indicating that they have either a reduced proliferative capacity or an increased sensitivity to apoptosis. $\mathrm{CD} 56^{-}$and $\mathrm{CD} 56^{+} \mathrm{T}$ cells purified from PBMCs that were expanded with PHA and IL-2 were used as effectors in ${ }^{51}$ chromium-release cytotoxicity assays against the K562 target cell line. Figure 2B illustrates that $\mathrm{CD} 56^{+}$ $\mathrm{T}$ cells displayed moderate cytotoxicity, giving a mean specific lysis of $9 \%$ at effector/target ratios of 50:1, whereas $\mathrm{CD} 56^{-} \mathrm{T}$ cells displayed negligible $(0.23 \%)$ cytotoxicity.

\section{Kinetics of Activation Marker Expression by Resting and Activated $\mathrm{CD} 56^{+}$and $\mathrm{CD} 56^{-} \mathrm{T}$ Cells}

Flow cytometric analysis of freshly isolated PBMCs revealed that the early activation marker, CD69, was not expressed by resting $\mathrm{CD} 56^{-} \mathrm{T}$ cells, but was present on up to $55 \%$ (mean $24 \%$ ) of $\mathrm{CD} 56^{+} \mathrm{T}$ cells (Figure 3 ). Within 1 hour of culture with PMA and ionomycin, both cell subsets expressed CD69, and by 24 hours this activation marker was expressed by all lymphocytes (data not shown). Significantly higher frequencies of $\mathrm{CD} 56^{+}$ (mean 63.9\%) compared with $\mathrm{CD}^{-} 6^{-}$(mean $31.1 \%, p<$ 0.001) $\mathrm{T}$ cells upregulated $\mathrm{CD} 69$ in response to antiCD3 mAb stimulation, peaking at 24 hours for both lymphocyte subsets (Figure 3). CD25 was found to be 
A

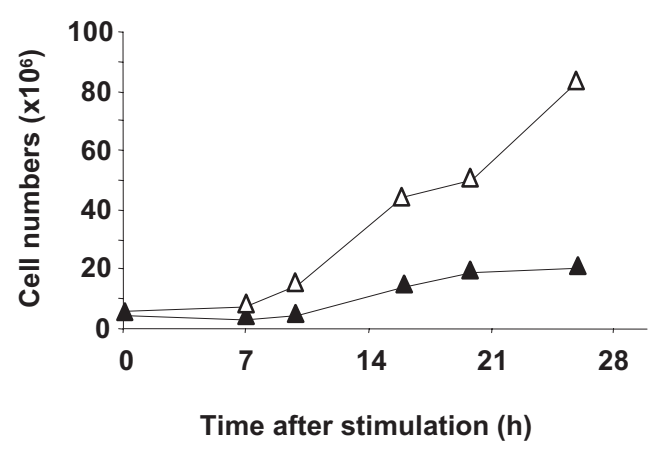

B

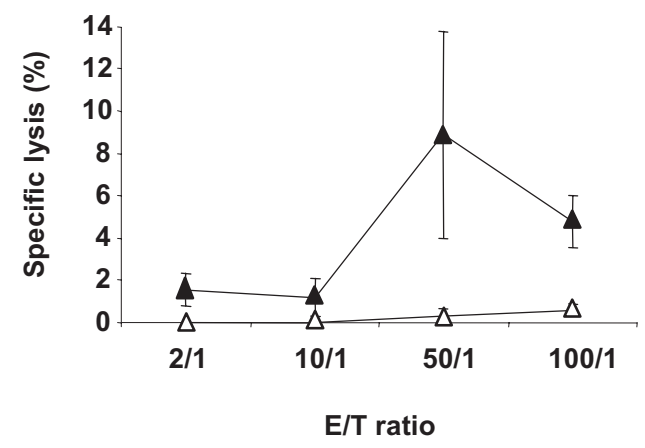

\begin{tabular}{|ll}
\hline$\Delta$ & CD56 \\
\hline & T cells \\
CD56- T cells
\end{tabular}

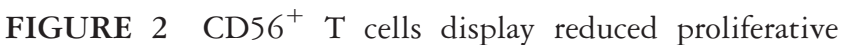
capacity and enhanced major histocompatibility complex-unrestricted cytotoxicity compared to $\mathrm{CD}^{5} 6^{-} \mathrm{T}$ cells. (A) Viable cell numbers recovered at various times after stimulation of 5 $\times 10^{6} \mathrm{CD} 6^{+}$or $\mathrm{CD}_{5} 6^{-} \mathrm{T}$ cells purified from PBMCs. (B) Specific lysis of K562 target cells by CD $56^{+}$and CD $56^{-} \mathrm{T}$ cells purified from PBMCs expanded with phytohemagglutinin and IL-2. Results are means of three experiments. E/T = effector/target ratio. Error bars illustrate standard errors of the means.

expressed by less than $17 \%$ of resting $\mathrm{CD}^{+} 6^{+}$and $\mathrm{CD} 56^{-} \mathrm{T}$ cells, but its expression was induced on $100 \%$ of $\mathrm{T}$ cells within 72 hours of activation with PMA and ionomycin (data not shown), and $75.1 \%$ and $64 \%$ of $\mathrm{CD} 56^{+}$and $\mathrm{CD} 56^{-} \mathrm{T}$ cells, respectively, stimulated with anti-CD3 mAb for 96 hours (Figure 3). HLA-DR was expressed by $<5 \%$ of freshly isolated PBMCs but was induced on about $50 \%$ of $\mathrm{CD} 56^{+}$and $\mathrm{CD} 56^{-} \mathrm{T}$ cells in response to 48 hours stimulation with PMA and ionomycin (data not shown), and about $10 \%$ of both cell populations following anti-CD3 mAb stimulation (Figure 3). CD $45 \mathrm{RO}$ was expressed by around $29 \%$ of resting $\mathrm{CD} 56^{+}$and $\mathrm{CD} 56^{-} \mathrm{T}$ cells. This antigen was slowly induced on $\mathrm{CD} 56^{+}$and $\mathrm{CD} 56^{-} \mathrm{T}$ cells by stimulation with PMA and ionomycin over a 5-day period, reaching maximum frequencies of $60 \%$ of $\mathrm{CD}^{-} 6^{-} \mathrm{T}$ cells and
$40 \%$ of $\mathrm{CD} 56^{+} \mathrm{T}$ cells (not shown). However, CD $45 \mathrm{RO}$ was not induced on either cell type by anti-CD3 activation (Figure 3).

CD $56^{+}$T Cells Release IFN- $\gamma$ and IL-13, but Not IL-10, Upon CD3 Stimulation

PBMCs were expanded with PHA and IL-2, and CD $56^{+}$ and $\mathrm{CD}^{-} 6^{-} \mathrm{T}$ cells were purified by selection with $\mathrm{mAb}$-coated magnetic beads. Similar numbers of $\operatorname{CD} 56^{+}$ and $\mathrm{CD} 56^{-} \mathrm{T}$ cells were stimulated with anti-CD3 $\mathrm{mAb}$ bound to microwell plates at varying concentrations. After 24,48 , or 72 hours, supernatants were collected and assayed for IFN- $\gamma$, IL-13, and IL-10 by ELISA. Figure 4 demonstrates that IFN- $\gamma$ release by both lymphocyte subsets was detectable 24 hours after stimulation with $0.03-3 \mu \mathrm{g} / \mathrm{ml}$ anti-CD3 $\mathrm{mAb}$. Consistently higher amounts of IFN- $\gamma$ were released by $\mathrm{CD} 56^{+} \mathrm{T}$ cells compared with similar numbers of $\mathrm{CD} 56^{-} \mathrm{T}$ cells after 48 hours $(p=0.04)$ and 72 hours $(p=0.01)$. The kinetics of IFN- $\gamma$ secretion by both cell types was similar, increasing gradually from $0-72$ hours. IL-13 was released by both $\mathrm{CD} 56^{+}$and $\mathrm{CD} 56^{-} \mathrm{T}$ cells in similar amounts and with similar kinetics after stimulation with $0.03-3 \mu \mathrm{g} / \mathrm{ml}$ anti-CD3 $\mathrm{mAb}$ (Figure 4). Purified $\mathrm{CD}_{56} 6^{-} \mathrm{T}$ cells consistently released moderate amounts

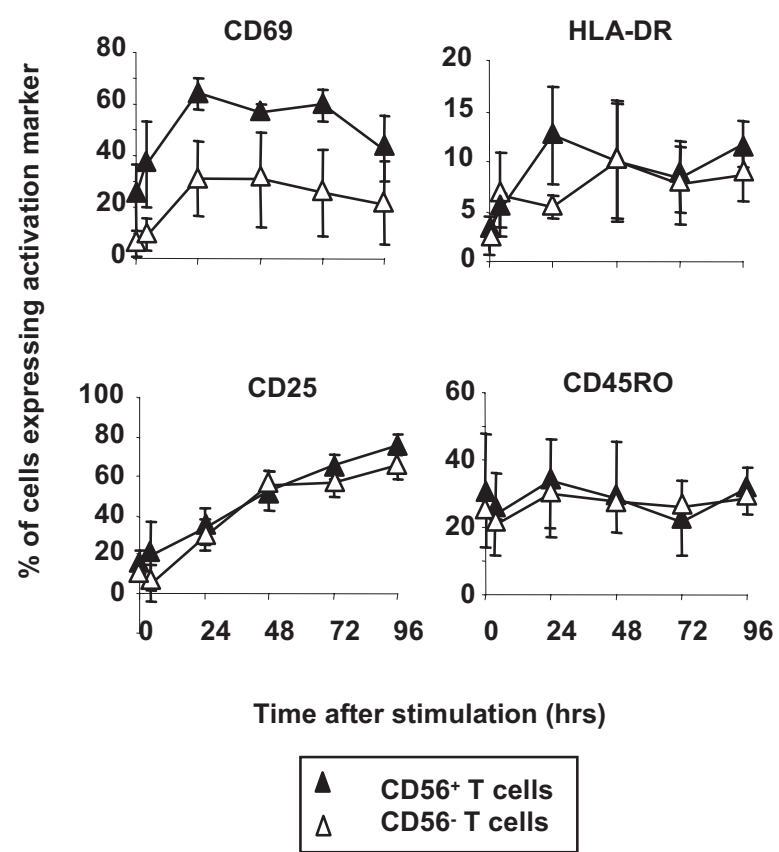

FIGURE 3 Kinetics of activation marker expression by $\mathrm{CD}_{5} 6^{+}$and $\mathrm{CD}_{5} 6^{-} \mathrm{T}$ cells after PBMC stimulation with 0.3 $\mu \mathrm{g} / \mathrm{ml}$ plate-bound anti-CD $3 \mathrm{mAb}$. Results demonstrate mean frequencies of $\mathrm{CD}_{5} 6^{+}$and $\mathrm{CD} 56^{-} \mathrm{T}$ cells in three samples that express CD69, HLA-DR, CD25, and CD45RO, as determined by flow cytometry. Error bars illustrate standard errors of the means. 

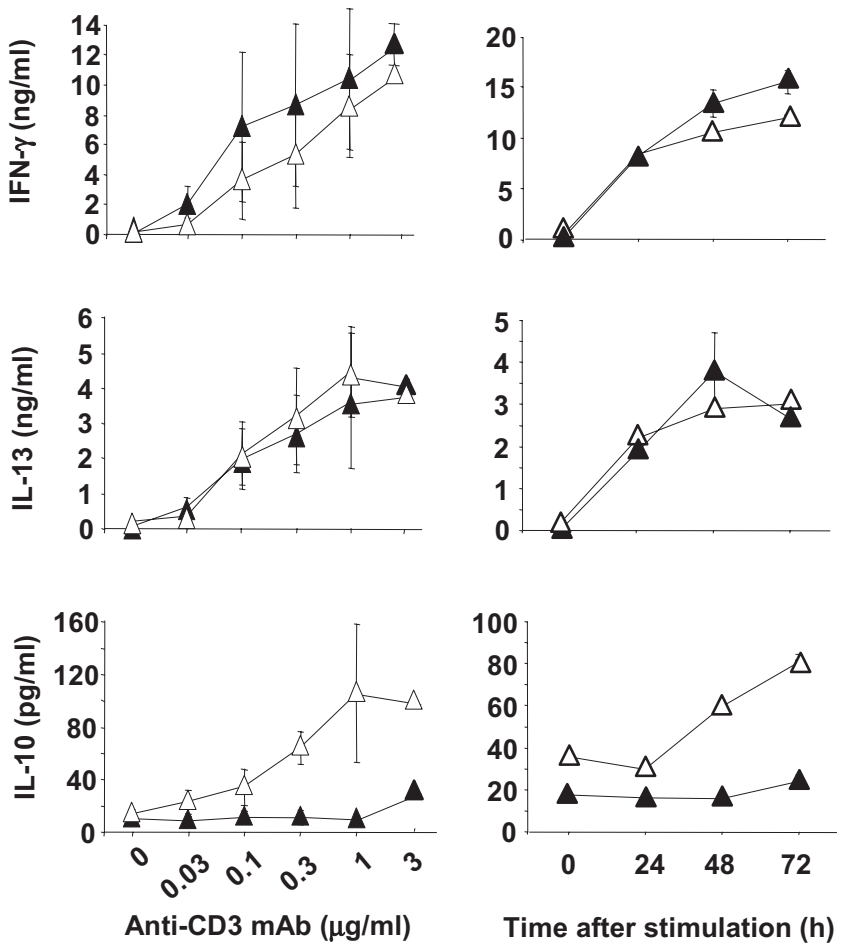

\section{$\triangle \quad$ CD56+ $T$ cells \\ $\triangle \quad$ CD56- $T$ cells}

FIGURE 4 Quantification of cytokine secretion by $\mathrm{CD} 56^{+}$ and $\mathrm{CD}^{-} 6^{-} \mathrm{T}$ cells after stimulation with plate-bound anti$\mathrm{CD} 3$ monoclonal antibody (mAb). Left, mean levels of interferon-gamma (IFN- $\gamma$ ) and IL-13 released after 48 hours and IL-10 released after 72 hours, after stimulation with $0-3$ $\mu \mathrm{g} / \mathrm{ml}$ anti-CD3 $\mathrm{mAb}$ as measured by enzyme linked immunosorbent assay (means of six experiments). Right, kinetics of IFN- $\gamma$, IL-13, and IL-10 release after stimulation with 0.3 $\mu \mathrm{g} / \mathrm{ml}$ anti-CD $3 \mathrm{mAb}$ (means of three experiments). Error bars illustrate standard errors of the means.

of IL-10 at 48-72 hours after stimulation with $0.03-3$ $\mu \mathrm{g} / \mathrm{ml}$ anti-CD3 $\mathrm{mAb}$, whereas little or no IL-10 was secreted by resting or stimulated $\mathrm{CD} 56^{+} \mathrm{T}$ cells (Figure $4)$. The differences in IL-10 levels released by $\operatorname{CD} 56^{+}$ and $\mathrm{CD} 56^{-} \mathrm{T}$ cells were significant at 48 hours $(p=$ $0.006)$ and 72 hours $(p=0.01)$ after stimulation. These data indicate that $\operatorname{CD} 56^{+} \mathrm{T}$ cells can release Th1 and Th2 cytokines upon stimulation, but unlike $\mathrm{CD}^{-} 6^{-} \mathrm{T}$ cells, they cannot be induced to release the regulatory cytokine IL-10 by TCR stimulation.

\section{CD $56^{+} \mathrm{T}$ Cells Rapidly Express Intracellular Cytokines Upon Activation}

Figure 4 illustrates that $\mathrm{CD} 56^{+} \mathrm{T}$ cells release IFN- $\gamma$ and IL-13, whereas $\mathrm{CD} 56^{-} \mathrm{T}$ cells can release IFN- $\gamma$, IL-13, and IL-10 within 24 hours of stimulation with anti-CD $3 \mathrm{mAb}$. Since $\mathrm{CD} 56^{+} \mathrm{T}$ cells display properties of innate lymphocytes, it is possible that they become activated to release cytokines in the first few hours after activation. We investigated the early kinetics of intracellular cytokine expression by $\mathrm{CD} 56^{+}$and $\mathrm{CD} 56^{-} \mathrm{T}$ cells within freshly isolated PBMCs from five donors by using flow cytometry (Figure 5A). No IFN- $\gamma$ was expressed by unstimulated cells. IFN- $\gamma$ was expressed by significant proportions of $\mathrm{CD} 56^{+} \mathrm{T}$ cells (mean 30.3\%) and $\mathrm{CD}^{-1} 6^{-} \mathrm{T}$ cells (mean $10 \%$ ) within $2-6$ hours of PBMC stimulation with PMA and ionomycin (Figure 5B). Lower proportions of $\mathrm{CD} 56^{+} \mathrm{T}$ cells (mean $4.5 \%$ ) and $\mathrm{CD} 56^{-} \mathrm{T}$ cells (mean $1.2 \%$ ) expressed IFN- $\gamma$ after stimulation with anti-CD $3 \mathrm{mAb}$. The proportions of $\mathrm{CD} 56^{+} \mathrm{T}$ cells that produced IFN- $\gamma$, after both types of stimulation, were significantly higher than those of CD 56 ${ }^{-} \mathrm{T}$ cells $(p=0.004$ for PMA and ionomycin stimulation and $p=0.03$ for anti-CD3 mAb stimulation). The mean intensities of fluorescence staining for IFN- $\gamma$ were similar for $\mathrm{CD} 56^{+}$and $\mathrm{CD} 56^{-} \mathrm{T}$ cells, suggesting that similar amounts of IFN- $\gamma$ were produced by both cell types (Figure 5A).

Significant frequencies of $\mathrm{CD} 56^{+} \mathrm{T}$ cells (mean $8.4 \%$ ) and $\mathrm{CD} 56^{-} \mathrm{T}$ cells (mean $1.5 \%$ ) produced IL-4 after PBMC stimulation for up to 6 hours with PMA and ionomycin, and lower percentages (means 5.2\% and $0.9 \%$, respectively) produced IL- 4 after anti-CD3 $\mathrm{mAb}$ stimulation (Figure 5B). Consistently higher frequencies of $\mathrm{CD} 56^{+} \mathrm{T}$ cells produced IL-4 compared with $\mathrm{CD} 56^{-}$ T cells $(p=0.03$ for PMA and ionomycin and $p=0.02$ for anti-CD3 mAb). Intracellular IL-13 was also detected in significantly greater frequencies of $\mathrm{CD}^{+} 6^{+} \mathrm{T}$ cells compared with $\mathrm{CD} 56^{-} \mathrm{T}$ cells (after 4 hours means $8.4 \%$ and $1.5 \%$, respectively, $p=0.01$ for PBMC stimulation with PMA and ionomycin and means $3.0 \%$ and $0.5 \%$, respectively, $p=0.001$ for stimulation with anti-CD3 $\mathrm{mAb}$, Figure 5B). IL-5 and IL-10 were expressed by very low proportions $(<3 \%)$ of $\mathrm{CD} 56^{-}$and $\mathrm{CD} 56^{+} \mathrm{T}$ cells after stimulation of the PBMCs with PMA and ionomycin or anti-CD3 mAb (Figure $5 \mathrm{~B}$ ).

\section{DISCUSSION}

$\mathrm{CD} 56^{+} \mathrm{T}$ cells belong to a heterogenous group of human $\mathrm{T}$ cells that express various stimulatory, costimulatory, inhibitory, and adhesion receptors that control NK cell activity [3-5, 33-35]. T cells with NKRs, including $\mathrm{CD} 56^{+} \mathrm{T}$ cells, are often present in cultures of stimulated $T$ cells $[4,11,13-17]$, and they frequently express memory phenotypes $[2,36,37]$. They can be activated by TCR ligation and by antigen-nonspecific signals through NKRs and cytokine receptors $[4,11,25,33-$ 351 and display potent MHC-unrestricted cytotoxicity against a range of tumor cells in vitro and in vivo [3, 11, $12,18,19,25]$. 
A

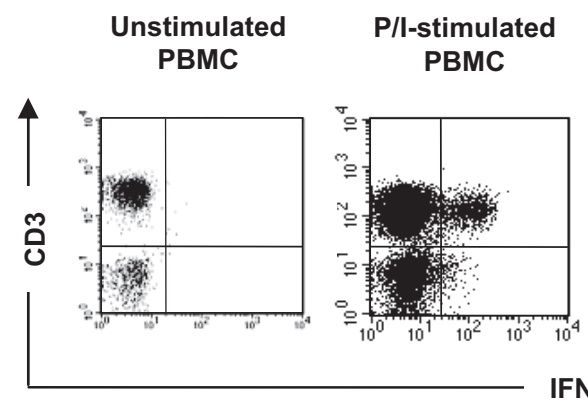

P/l-stimulated CD56- $T$ cells

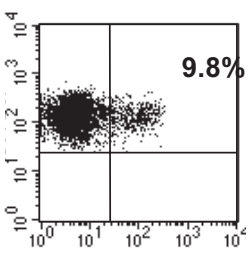

P/l-stimulated CD56+ $T$ cells

IFN- $\gamma$
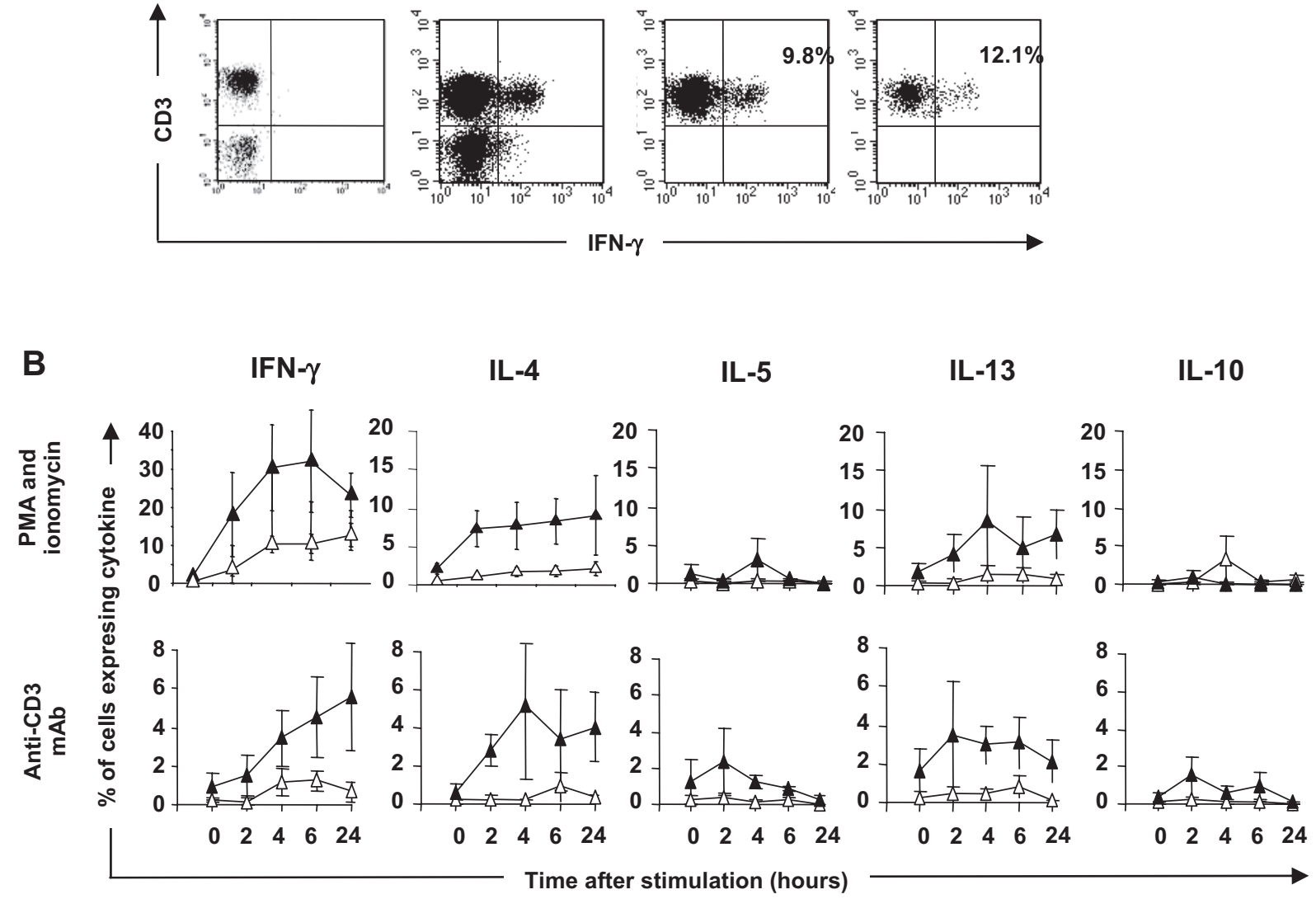

\begin{tabular}{|ll|}
\hline$\Delta$ & CD56 $^{+} \mathrm{T}$ cells \\
$\Delta$ & CD56- $\mathrm{T}$ cells \\
\hline
\end{tabular}

FIGURE 5 Flow cytometric detection of intracellular cytokine expression by $\mathrm{CD} 56^{+}$and $\mathrm{CD} 56^{-} \mathrm{T}$ cells after stimulation of fresh PBMCs with phorbol myristate acetate (PMA) and ionomycin (P/I), or $0.3 \mu \mathrm{g} / \mathrm{ml}$ plate-bound anti-CD3 mAb. (A) Representative flow cytometric dot plots of IFN- $\gamma$ expression by unstimulated and PMA and ionomycin-stimulated total PBMCs, and PMA and ionomycin-stimulated electronically gated $\mathrm{CD}^{-} 6^{-}$and $\mathrm{CD} 6^{+} \mathrm{T}$ cell subsets. (B) Kinetics of IFN- $\gamma$, IL-4, IL-5, IL-13, and IL-10 expression by $\operatorname{CD} 56^{+}$and $\operatorname{CD} 56^{-} \mathrm{T}$ cells after stimulation of PBMCs with PMA and ionomycin (top) or anti-CD $3 \mathrm{mAb}$ (bottom). Results are means of five experiments for IFN- $\gamma$ and IL-4, and three experiments for IL-5, IL-13, and IL-10. Error bars illustrate standard errors of the means.

Many $\mathrm{NKR}^{+} \mathrm{T}$ cells can recognize nonprotein components of pathogens and host cells. Such "innate lymphocytes" include NKT cells, which recognize glycolipids presented by the MHC class I-like molecule CD1d $[27,38]$, and $\gamma \delta \mathrm{T}$ cells, which respond to soluble metabolites, heat shock proteins, or glycolipids presented by CD1c [26]. NKT cells and $\gamma \delta \mathrm{T}$ cells most notably display rapid Th1, Th2, and/or regulatory cytokine secretion and are thought to be important for the initiation, polarization, and regulation of adaptive immune responses [24, 39-42]. Defects in cytokine production by NKT cells and $\gamma \delta \mathrm{T}$ cells have been associated with failure to eliminate pathogens and tumors and the development of autoimmune diseases in murine models and in humans $[26,27,38]$. Human $\mathrm{CD}^{2} 6^{+} \mathrm{T}$ cells display functional similarities (responsiveness to innate cytokines and MHC-unrestricted cytotoxicity) to these innate lymphocytes $[3,4,11,12,18,19,25,33,34]$ and are altered in disease $[23,28-32]$, but it is not clear whether these cells can similarly initiate and/or regulate adaptive immune responses.

In the present study, we confirm previous reports that

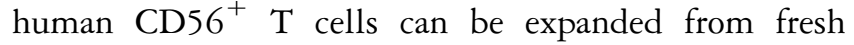
PBMCs by TCR-mediated activation, particularly when grown in the presence of exogenous IL-2 [4, 11, 13-17]. We found that a single CD3/TCR stimulation of PBMCs in the absence of added growth factors resulted in threefold expansions of $\operatorname{CD} 56^{+} \mathrm{T}$ cells but no increase in total 
cell numbers. Expansion of PBMCs by two rounds of PHA stimulation and culturing with IL-2 resulted in a mean 37-fold increase in $\mathrm{CD} 56^{+} \mathrm{T}$ cell numbers, expanding from $3 \%-27 \%$ of all $\mathrm{T}$ cells in 28 days. Consistent with previous reports that CD56 is present on T cells at a later stage of differentiation [13], purified expanded $\mathrm{CD} 56^{+} \mathrm{T}$ cells displayed a lower proliferative potential than $\mathrm{CD}_{5} 6^{-} \mathrm{T}$ cells from the same cultures. As previously reported $[11,25], \mathrm{CD} 56^{+} \mathrm{T}$ cells, only, were capable of killing the NK-sensitive target cell line, K562, but this cytolytic activity was less potent than that of NK cells. We found that PHA and IL-2-induced expansions of $\mathrm{CD} 56^{+} \mathrm{T}$ cells are the result both of the induction of $\mathrm{CD} 56$ expression by $\mathrm{CD} 56^{-} \mathrm{T}$ cells and of the proliferation of $\mathrm{CD} 56^{+} \mathrm{T}$ cells. Expansion of PBMCs that were first depleted of $\mathrm{CD} 56^{+} \mathrm{T}$ cells with PHA and IL-2 resulted in the expression of CD56 by a mean of $37 \%$ of $\mathrm{T}$ cells after 28 days. This suggests that CD 56 can be induced on $\mathrm{T}$ cells by activation. It is possible that the $\mathrm{CD} 56^{+} \mathrm{T}$ cells in these cultures arose from expansions of small numbers of contaminating $\operatorname{CD} 56^{+} \mathrm{T}$ cells; however, we feel that this is unlikely since $\operatorname{CD} 56^{+} \mathrm{T}$ cells were found to proliferate less vigorously than CD56 $6^{-} \mathrm{T}$ cells.

Phenotypic analysis of $\mathrm{CD} 56^{+} \mathrm{T}$ cells generated by mitogen activation and culturing with IL-2 in vitro indicated that $\mathrm{CD} 56$ is induced on $\mathrm{CD}^{+}$and doublenegative $\mathrm{CD} 4^{-} \mathrm{CD} 8^{-} \mathrm{T}$ cells, but not $\mathrm{CD} 4^{+} \mathrm{T}$ cells, even though $\mathrm{CD}_{5} 6^{+} \mathrm{T}$ cells expressing $\mathrm{CD} 4$ were present in fresh blood. $\mathrm{CD}^{+}, \mathrm{CD}^{+}$, and doublenegative $\operatorname{CD} 56^{+} \mathrm{T}$ cells are also present in the liver $[6$, 7] and the small intestine [8-10]. CD56 was induced on $\alpha \beta \mathrm{T}$ cells and NKT cells expressing the invariant V $\alpha 24 \mathrm{~J} \alpha 18$ TCR but less frequently on $\gamma \delta \mathrm{T}$ cells, even though $\mathrm{CD} 6^{+} \gamma \delta \mathrm{T}$ cells are present in significant numbers in blood. The phenotypic differences between naturally occurring and ex vivo activation-induced $\mathrm{CD} 56^{+} \mathrm{T}$ cells indicate that different signals are required for the expansion of different populations of $\mathrm{CD} 6^{+} \mathrm{T}$ cells, and the changes in $\mathrm{CD} 56^{+} \mathrm{T}$ cell numbers in disease [23, 28-32] may reflect changes in subpopulations of this group of cells.

Examination of activation marker expression by freshly isolated PBMC subsets by flow cytometry revealed that the early activation marker, CD69, is expressed by greater frequencies of $\mathrm{CD} 56^{+} \mathrm{T}$ cells compared with $\mathrm{CD}_{5} 6^{-} \mathrm{T}$ cells, but CD25, HLA-DR, and CD45RO are expressed by similar proportions of each lymphocyte subset. Each activation marker examined was induced on a proportion of $\mathrm{CD} 56^{+}$and $\mathrm{CD} 56^{-} \mathrm{T}$ cells with similar kinetics after treatment with PMA and ionomycin, but CD69 and CD25, only, were induced on significant proportions of both $\mathrm{T}$ cell subsets following anti-CD $3 \mathrm{mAb}$ stimulation. Since both $\mathrm{CD}^{+} 6^{+}$and
$\mathrm{CD} 56^{-} \mathrm{T}$ cells in fresh PBMCs include cells that are positive and cells that are negative for activation markers, and since both $\mathrm{T}$ cell subsets demonstrate similar kinetics of activation marker expression following activation, it is possible that $\mathrm{CD} 56^{+} \mathrm{T}$ cells in fresh blood include both naive and effector $\mathrm{T}$ cells. Further studies are required to ascertain whether induced $\mathrm{CD} 56^{+} \mathrm{T}$ cells express memory cell phenotypes. Our observations also suggest that $\operatorname{CD} 56^{+} \mathrm{T}$ cells are not activated more rapidly than $\mathrm{CD} 56^{-} \mathrm{T}$ cells.

We examined the cytokine secretion profiles of human $\mathrm{CD} 56^{+} \mathrm{T}$ cells to determine whether they display the rapid Th1/Th2/regulatory cytokine secretion properties that are characteristic of innate lymphocytes, such as NKT cells and $\gamma \delta \mathrm{T}$ cells $[24,39-42] . \mathrm{CD} 56^{+}$and $\mathrm{CD} 56^{-} \mathrm{T}$ cells were purified from PHA and IL-2expanded PBMC cultures by $\mathrm{mAb}$-coated magnetic bead selection. Similar numbers of purified $\mathrm{CD}^{2} 6^{+}$and $\mathrm{CD} 56^{-} \mathrm{T}$ cells were given a single stimulation with varying amounts of crosslinking anti-CD $3 \mathrm{mAb}$, and samples of supernatant were removed at various times poststimulation for analysis of IFN- $\gamma$, IL-13, and IL-10 levels by ELISA. As previously reported for sorted CD8 ${ }^{+}$ CD56 ${ }^{+} \mathrm{T}$ cells $[3,5], \mathrm{CD} 56^{+} \mathrm{T}$ cells were found to release higher levels of the Th1 cytokine, IFN- $\gamma$ than did similar numbers of $\mathrm{CD} 56^{-} \mathrm{T}$ cells. We found that the kinetics of IFN- $\gamma$ release were similar for both lymphocyte subsets, with maximal levels detectable after 48 hours. Furthermore, the strengths of the stimuli, based on the concentrations of anti-CD3 $\mathrm{mAb}$ used, required to induce IFN- $\gamma$ release were the same for $\operatorname{CD} 56^{+}$and CD $56^{-} \mathrm{T}$ cells. Similar amounts of the Th2 cytokine, IL-13, were released by $\mathrm{CD}_{5} 6^{+}$and $\mathrm{CD} 56^{-} \mathrm{T}$ cells following the same stimulus strengths and similar kinetics. However, $\mathrm{CD} 56^{+} \mathrm{T}$ cells could not be induced to release IL-10, whereas $\mathrm{CD}^{-} 6^{-} \mathrm{T}$ cells consistently released significant amounts of this regulatory cytokine within 48 hours of stimulation with anti-CD3 $\mathrm{mAb}$. The differences in IL-10 secretion by $\mathrm{CD} 56^{+}$and $\mathrm{CD} 56^{-} \mathrm{T}$ cells were significant. Our data indicate that $\operatorname{CD} 56^{+} \mathrm{T}$ cells can promote Th1 or Th2 responses but are unlikely to regulate them via IL-10 secretion.

We investigated whether $\mathrm{CD} 56^{+} \mathrm{T}$ cells are more likely to produce cytokines than $\mathrm{CD} 56^{-} \mathrm{T}$ cells at the early stages (2-24 hours) after stimulation, by activating fresh PBMCs in the presence of brefeldin $\mathrm{A}$ and determining the percentages of $\mathrm{CD} 56^{+}$and $\mathrm{CD} 56^{-} \mathrm{T}$ cells that express intracellular IFN- $\gamma$, IL-4, IL- 5 , IL-13, or IL-10, by flow cytometry. We found that IFN- $\gamma$, IL- 4 and IL-13, but not IL-5 or IL-10, were expressed by significant proportions of $\mathrm{CD} 56^{+} \mathrm{T}$ cells within 2 hours of stimulation with either PMA and ionomycin or antiCD3 mAb. Significantly lower proportions of $\mathrm{CD}_{5} 6^{-} \mathrm{T}$ cells expressed these cytokines. IFN- $\gamma$ and IL- 4 have 
previously been shown to be expressed by higher frequencies of $\mathrm{CD} 56^{+}$compared with $\mathrm{CD} 56^{-} \mathrm{T}$ cells upon 4 hours of stimulation in fresh peripheral blood [4] and liver [15, 25] mononuclear cells. In contrast, Loza et al., used flow cytometry to demonstrate that IFN- $\gamma$ expression is higher, but IL- 4 and IL-13 expression is lower, in $\mathrm{CD} 56^{+} \mathrm{T}$ cells compared with $\mathrm{CD} 56^{-} \mathrm{T}$ cells in cultures that were matured with IL-2, IL-12, IL-18, and/or IFN- $\alpha$, indicating that the culture conditions used to generate $\mathrm{CD} 56^{+} \mathrm{T}$ cells are likely to influence the cytokine profiles [13]. For this reason, we avoided using Th cell polarizing cytokines, such as IL- 12 or IFN- $\gamma$, to expand $\mathrm{CD} 56^{+} \mathrm{T}$ cells, as was done for the generation of antitumor cytokine-induced killer cells $[11,13-17]$. Anfossi and coworkers have demonstrated that murine and human $\mathrm{CD}^{+} \mathrm{T}$ cells that express other NKRs (Ly49 or killer immunoglobulinlike receptors), display reduced frequencies of IFN- $\gamma$ and TNF- $\alpha$ expression compared with $\mathrm{NKR}^{-} \mathrm{CD}^{+}{ }^{+} \mathrm{T}$ cells $[43,44]$, whereas Kambayashi et al. reported that murine influenza-specific $\mathrm{NKR}^{+} \mathrm{T}$ cells produce IFN- $\boldsymbol{\gamma}$ in response to influenza antigens [45].

Our combined ELISA and flow cytometry results indicate that human $\operatorname{CD} 56^{+} \mathrm{T}$ cells are more likely to produce Th1 (IFN- $\gamma$ ) and Th2 (IL-4 and IL-13) cytokines than $\mathrm{CD} 56^{-} \mathrm{T}$ cells at early times poststimulation, that $\mathrm{CD} 56^{+} \mathrm{T}$ cells release higher amounts of IFN- $\gamma$ but similar amounts of IL-13 compared with $\mathrm{CD} 56^{-} \mathrm{T}$ cells after 48 hours, and that $\operatorname{CD} 56^{+} \mathrm{T}$ cells do not produce IL-5 or IL-10. The apparent differences in cytokine production as detected by flow cytometry and ELISA may reflect different cytokine-mediated functions at different stages of an immune response. Cytokines released at an early stage after activation are likely to be directed into the immunologic synapse between the $\mathrm{T}$ cell and antigen-presenting cell, and very small quantities of cytokine may be sufficient to saturate this microenvironment. In contrast, the large amounts of cytokine that accumulate in supernatants over 48 hours, and that are detectable by ELISA, are more likely to target multiple cells in the region of the $\mathrm{T}$ cell. These two scenarios of cytokine secretion are mediated by two directionally distinct export pathways [46]. The enhanced ability of some $\mathrm{CD} 56^{+} \mathrm{T}$ cells to produce cytokines at an early stage suggests that they can function as innate lymphocytes like CD1-restricted NKT cells and $\gamma \delta \mathrm{T}$ cells, which can stimulate maturation of dendritic cells [47, 48] into antigen-presenting cells as well as releasing Th1/Th2 cytokines.

Our data indicate that CD56 expression can be induced on $\mathrm{CD} 56^{-} \mathrm{T}$ cells by TCR-mediated activation, and that the expression of this marker is associated with altered cytokine secretion profiles in addition to the acquisition of MHC-unrestricted cytotoxic activity. The acquisition of MHC-unrestricted cytotoxic activity by $\mathrm{CD} 56^{+} \mathrm{T}$ cells would allow them to kill target cells in an antigen-nonspecific manner, perhaps as a means to combat pathogens and tumors that undergo antigenic drift and can evade conventional MHC-restricted T cells. Their ability to release IFN- $\boldsymbol{\gamma}$ and IL-13 in response to TCR stimulation indicates that they can also promote Th1 and Th2 responses. In contrast to $\mathrm{CD}_{5} 6^{-} \mathrm{T}$ cells, activation-induced $\mathrm{CD} 56^{+} \mathrm{T}$ cells do not secrete IL-10. Thus, $\mathrm{CD} 56^{+} \mathrm{T}$ cells may emerge in parallel with inducible regulatory $\mathrm{T}$ cells [49] and may provide a counter-regulatory cell population that can activate adaptive immune responses in certain tissues. This could occur in the liver and intestine, where tolerance is favored over active immunity and where $\mathrm{CD} 56^{+} \mathrm{T}$ cells are particularly abundant $[6-10]$. The ease by which $\mathrm{CD} 56^{+} \mathrm{T}$ cells can be expanded from PBMCs supports their use as possible therapeutic modulators of immune responses in infectious and immune-mediated diseases, in addition to their potential as antitumor cytotoxic effector cells.

\section{ACKNOWLEDGMENTS}

This work was supported by grants from the Irish Health Research Board (BPRB/02/2003), Science Foundation Ireland (04/BR/B0427), and Enterprise Ireland (SC/2000/365).

\section{REFERENCES}

1. Lanier LL, Le AM, Civin CI, Loken MR, Phillips JH: The relationship of CD16 (Leu-11) and Leu-19 (NKH-1) antigen expression on human peripheral blood NK cells and cytotoxic $\mathrm{T}$ lymphocytes. J Immunol 136:4480, 1986.

2. Schmidt RE, Murray C, Daley JF, Schlossman SF, Ritz J: A subset of natural killer cells in peripheral blood displays a mature T cell phenotype. J Exp Med 164:351, 1986.

3. Ortaldo JR, Winkler-Pickett RT, Yagita H, Young HA: Comparative studies of $\mathrm{CD}^{-}$and $\mathrm{CD}^{+}{ }^{+} \mathrm{CD} 56^{+}$cells: examination of morphology, functions, $\mathrm{T}$ cell receptor rearrangement, and pore-forming protein expression. Cell Immunol 136:486, 1991.

4. Dunne J, Lynch S, O'Farrelly C, Todryk S, Hegarty JE, Feighery C, Doherty DG: Selective expansion and partial activation of human NK cells and NK receptor-positive T cells by IL-2 and IL-15. J Immunol 167:3129, 2001.

5. Ohkawa T, Seki S, Dobashi H, Koike Y, Habu Y, Ami K, Hiraide H, Sekine I: Systematic characterization of human $\mathrm{CD}^{+} \mathrm{T}$ cells with natural killer cell markers in comparison with natural killer cells and normal $\mathrm{CD}^{+} \mathrm{T}$ cells. Immunology 103:281, 2001.

6. Norris S, Doherty DG, Collins C, McEntee G, Traynor O, Hegarty JE, O'Farrelly C: Natural T cells in the human liver: cytotoxic lymphocytes with dual $\mathrm{T}$ cell and natural killer cell phenotype and function are phenotypically het- 
erogenous and include $\mathrm{V} \alpha 24-\mathrm{J} \alpha \mathrm{Q}$ and $\gamma \delta \mathrm{T}$ cell receptor bearing cells. Hum Immunol 60:20, 1999.

7. Ishihara S, Nieda M, Kitayama J, Osada T, Yabe T, Ishikawa $\mathrm{Y}$, Nagawa $\mathrm{H}$, Muto T, Juji T: $\mathrm{CD}^{+}$NKR$\mathrm{P} \mathrm{A}^{+} \mathrm{T}$ cells preferentially accumulate in human liver. Eur J Immunol 29:2406, 1999.

8. Bannai M, Kawamura T, Naito T, Kameyama H, Abe T, Kawamura H, Tsukada C, Watanabe H, Hatakeyama K, Hamada H, Nishiyama Y, Ishikawa H, Takeda K, Okumura K, Taniguchi M, Abo T: Abundance of unconventional $\mathrm{CD}^{+}$natural killer $\mathrm{T}$ cells in the large intestine. Eur J Immunol 31:3361, 2001.

9. Iiai $\mathrm{T}$, Watanabe $\mathrm{H}$, Suda $\mathrm{T}$, Okamoto $\mathrm{H}$, Abo $\mathrm{T}$, Hatakeyama K: $\mathrm{CD}_{161}{ }^{+} \mathrm{T}(\mathrm{NT})$ cells exist predominantly in human intestinal epithelium as well as in liver. Clin Exp Immunol 129:92, 2002.

10. O'Keeffe J, Doherty DG, Kenna T, Sheahan K, O’Donoghue DP, Hyland JM, O'Farrelly C. Diverse populations of T cells with NK cell receptors accumulate in the human intestine in health and in colorectal cancer. Eur J Immunol 34:2110, 2004.

11. Lu PH, Negrin RS: A novel population of expanded human $\mathrm{CD}^{+} \mathrm{CD}^{+} 6^{+}$cells derived from $\mathrm{T}$ cells with potent in vivo antitumor activity in mice with severe combined immunodeficiency. J Immunol 153:1687, 1994.

12. Pittet MJ, Speiser DE, Valmori D, Cerottini JC, Romero P: Cutting edge: cytolytic effector function in human circulating $\mathrm{CD}^{+} \mathrm{T}$ cells closely correlates with $\mathrm{CD} 56$ surface expression. J Immunol 164:1148, 2000.

13. Loza MJ, Metelitsa LS, Perussia B: NKT and T cells: coordinate regulation of NK-like phenotype and cytokine production. Eur J Immunol 32:3453, 2002.

14. Satoh M, Seki S, Hashimoto W, Ogasawara K, Kobayashi T, Kumagai K, Matsuno S, Takeda K: Cytotoxic $\gamma \delta$ or $\alpha \beta$ T cells with a natural killer cell marker, CD56, induced from human peripheral blood lymphocytes by a combination of IL-12 and IL-2. J Immunol 157:3886, 1996.

15. Jin Y, Fuller L, Carreno M, Esquenazi V, Tzakis AG, Miller J: The regulation of phenotype and function of human liver $\mathrm{CD}^{+} / \mathrm{CD} 56^{+}$lymphocytes, and cells that also co-express CD8 by IL-2, IL-12 and anti-CD3 monoclonal antibody. Hum Immunol 59:352, 1998.

16. Zoll B, Lefterova P, Csipai M, Finke S, Trojaneck B, Ebert O, Micka B, Roigk K, Fehlinger M, Schmidt-Wolf GD, Huhn D, Schmidt-Wolf IG: Generation of cytokineinduced killer cells using exogenous interleukin-2, -7 or -12. Cancer Immunol Immunother 47:221, 1998.

17. Kelly AM, Golden-Mason L, McEntee G, Traynor O, Doherty DG, Hegarty JE, O'Farrelly C: Interleukin 12 (IL-12) is increased in tumour bearing human liver and expands $\mathrm{CD}^{+}$and $\mathrm{CD}^{+} 6^{+} \mathrm{T}$ cells in vitro but not in vivo. Cytokine 25:273, 2004.

18. Schmidt-Wolf IG, Lefterova P, Mehta BA, Fernandez LP, Huhn D, Blume KG, Weissman IL, Negrin RS: Pheno- typic characterization and identification of effector cells involved in tumor cell recognition of cytokine-induced killer cells. Exp Hematol 21:1673, 1993.

19. Linn YC, Hui KM: Cytokine-induced killer cells: NKlike $\mathrm{T}$ cells with cytotolytic specificity against leukemia. Leuk Lymphoma 44:1457, 2003.

20. Schmidt-Wolf IG, Finke S, Trojaneck B, Denkena A, Lefterova P, Schwella N, Heuft HG, Prange G, Korte M, Takeya M, Dorbic T, Neubauer A, Wittig B, Huhn D: Phase I clinical study applying autologous immunologic effector cells transfected with the interleukin-2 gene in patients with metastatic renal cancer, colorectal cancer and lymphoma. Br J Cancer 81:1009, 1999.

21. Shi M, Zhang B, Tang ZR, Lei ZY, Wang HF, Feng YY, Fan ZP, Xu DP, Wang FS: Autologous cytokine-induced killer cell therapy in clinical trial phase I is safe in patients with primary hepatocellular carcinoma. World J Gastroenterol 10:1146, 2004.

22. Leemhuis T, Wells S, Scheffold C, Edinger M, Negrin RS: A phase I trial of autologous cytokine-induced killer cells for the treatment of relapsed Hodgkin disease and nonHodgkin lymphoma. Biol Blood Marrow Transplant 11: 181, 2005.

23. Barnaba V, Franco A, Paroli M, Benvenuto R, De Petrillo G, Burgio VL, Santilio I, Balsano C, Bonavita MS, Cappelli G, Colizzi V, Cutrona G, Ferrarini M: Selective expansion of cytotoxic $\mathrm{T}$ lymphocytes with a $\mathrm{CD} 4{ }^{+} \mathrm{CD} 56^{+}$surface phenotype and a $\mathrm{T}$ helper type 1 profile of cytokine secretion in the liver of patients chronically infected with Hepatitis B virus. J Immunol 152:3074, 1994.

24. Prussin C, Foster B: TCR V $\alpha 24$ and V $\beta 11$ coexpression defines a human NK1 $\mathrm{T}$ cell analog containing a unique Th0 subpopulation. J Immunol 159:5862, 1997.

25. Doherty DG, Norris S, Madrigal-Estebas L, McEntee G, Traynor O, Hegarty JE, O'Farrelly C: The human liver contains multiple populations of NK cells, $\mathrm{T}$ cells, and $\mathrm{CD}^{+}{ }^{+} \mathrm{CD}_{5} 6^{+}$natural $\mathrm{T}$ cells with distinct cytotoxic activities and Th1, Th2, and Th0 cytokine secretion patterns. J Immunol 163:2314, 1999.

26. Carding SR, Egan PJ: $\gamma \delta$ T cells: functional plasticity and heterogeneity. Nat Rev Immunol 2:336, 2002.

27. Kronenberg M: Toward an understanding of NKT cell biology: progress and paradoxes. Annu Rev Immunol 23:877, 2005.

28. Takii $Y$, Hashimoto S, Iiai T, Watanabe H, Hatakeyama $\mathrm{K}$, Abo $\mathrm{T}$ : Increase in the proportion of granulated $\mathrm{CD}^{+} 6^{+} \mathrm{T}$ cells in patients with malignancy. Clin Exp Immunol 97:522, 1994.

29. Meresse B, Curran SA, Ciszewski C, Orbelyan G, Setty M, Bhagat G, Lee L, Tretiakova M, Semrad C, Kistner E, Winchester RJ, Braud V, Lanier LL, Geraghty DE, Green PH, Guandalini S, Jabri B: Reprogramming of CTLs into natural killer-like cells in celiac disease. J Exp Med 203: $1343,2006$.

30. Deignan T, Curry MP, Doherty DG, Golden-Mason L, 
Volkov Y, Norris S, Nolan N, Traynor O, McEntee G, Hegarty JE, O'Farrelly C: Decrease in hepatic $\mathrm{CD}_{5} 6^{+} \mathrm{T}$ cells and $\mathrm{V} \alpha 24^{+}$natural killer $\mathrm{T}$ cells in chronic hepatitis C viral infection. J Hepatol 37:101, 2002.

31. Tarazona R, Casado JG, Delarosa O, Torre-Cisneros J, Villanueva JL, Sanchez B, Galiani MD, Gonzalez R, Solana R, Pena J: Selective depletion of $\mathrm{CD} 56^{\text {dim }} \mathrm{NK}$ cell subsets and maintenance of CD56 $6^{\text {bright }} \mathrm{NK}$ cells in treatment-naive HIV-1-seropositive individuals. J Clin Immunol 22:176, 2002.

32. Norris S, Doherty DG, Curry M, McEntee G, Traynor O, Hegarty JE, O'Farrelly C: Selective reduction of natural killer cells and $\mathrm{T}$ cells expressing inhibitory receptors for $\mathrm{MHC}$ class I in the livers of patients with hepatic malignancy. Cancer Immunol Immunother 52: 53, 2003.

33. Mingari MC, Vitale C, Cambiaggi A, Schiavetti F, Melioli G, Ferrini S, Poggi A: Cytolytic T lymphocytes displaying natural killer (NK)-like activity: expression of NK-related functional receptors for HLA class I molecules (p58 and CD94) and inhibitory effect on the TCR-mediated target cell lysis or lymphokine production. Int Immunol 7:697, 1995.

34. Mandelboim O, Kent S, Davis DM, Wilson SB, Okazaki T, Jackson R, Hafler D, Strominger JL: Natural killer activating receptors trigger interferon- $\gamma$ secretion from $T$ cells and natural killer cells. Proc Natl Acad Sci USA 95:3798, 1998.

35. McMahon CW, Raulet DH: Expression and function of $\mathrm{NK}$ cell receptors in $\mathrm{CD}^{+}{ }^{-} \mathrm{T}$ cells. Curr Opin Immunol 13:465, 2001.

36. Speiser DE, Valmori D, Rimoldi D, Pittet MJ, Lienard D, Cerundolo V, MacDonald HR, Cerottini JC, Romero P: CD28-negative cytolytic effector $\mathrm{T}$ cells frequently express NK receptors and are present at variable proportions in circulating lymphocytes from healthy donors and melanoma patients. Eur J Immunol 29:1990, 1999.

37. Ugolini S, Arpin C, Anfossi N, Walzer T, Cambiaggi A, Forster R, Lipp M, Toes RE, Melief CJ, Marvel J, Vivier E: Involvement of inhibitory NKRs in the survival of a subset of memory-phenotype $\mathrm{CD}^{+} \mathrm{T}$ cells. Nat Immunol 2:430, 2001.

38. Brigl M, Brenner MB: CD1: antigen presentation and T cell function. Annu Rev Immunol 22:817, 2004.
39. Exley M, Garcia J, Balk SP, Porcelli S: Requirements for CD1d recognition by human invariant $\mathrm{V} \alpha 24^{+}$ CD4 ${ }^{-} \mathrm{CD}^{-}{ }^{-} \mathrm{T}$ cells. J Exp Med 186:109, 1997.

40. Sonoda KH, Faunce DE, Taniguchi M, Exley M, Balk S, Stein-Streilein J: NK T cell-derived IL-10 is essential for the differentiation of antigen-specific $\mathrm{T}$ regulatory cells in systemic tolerance. J Immunol 166:42, 2001.

41. Ferrick DA, Schrenzel MD, Mulvania T, Hsieh B, Ferlin WG, Lepper H: Differential production of interferon- $\gamma$ and interleukin- 4 in response to Th1- and Th2-stimulating pathogens by $\gamma \delta \mathrm{T}$ cells in vivo. Nature 373:255, 1995.

42. Hsieh B, Schrenzel MD, Mulvania T, Lepper HD, DiMolfetto-Landon L, Ferrick DA: In vivo cytokine production in murine listeriosis. Evidence for immunoregulation by $\gamma \delta^{+}$T cells. J Immunol 156:232, 1996.

43. Anfossi N, Doisne JM, Peyrat MA, Ugolini S, Bonnaud O, Bossy D, Pitard V, Merville P, Moreau JF, Delfraissy JF, Dechanet-Merville J, Bonneville M, Venet A, Vivier $\mathrm{E}$ : Coordinated expression of Ig-like inhibitory MHC class I receptors and acquisition of cytotoxic function in human $\mathrm{CD}^{+} \mathrm{T}$ cells. J Immunol 173:7223, 2004.

44. Anfossi N, Robbins SH, Ugolini S, Georgel P, Hoebe K, Bouneaud C, Ronet C, Kaser A, DiCioccio CB, Tomasello E, Blumberg RS, Beutler B, Reiner SL, Alexopoulou L, Lantz O, Raulet DH, Brossay L, Vivier E: Expansion and function of $\mathrm{CD}^{+} \mathrm{T}$ cells expressing Ly49 inhibitory receptors specific for MHC class I molecules. J Immunol 173:3773, 2004.

45. Kambayashi T, Assarsson E, Michaelsson J, Berglund P, Diehl AD, Chambers BJ, Ljunggren HG: Emergence of $\mathrm{CD}^{+} \mathrm{T}$ cells expressing $\mathrm{NK}$ cell receptors in influenza $\mathrm{A}$ virus-infected mice. J Immunol 165:4964, 2000.

46. Huse M, Lillemeier BF, Kuhns MS, Chen DS, Davis MM: $\mathrm{T}$ cells use two directionally distinct pathways for cytokine secretion. Nat Immunol 7:247, 2006.

47. Leslie DS, Vincent MS, Spada FM, Das H, Sugita M, Morita CT, Brenner MB: CD1-mediated gd T cell maturation of dendritic cells. J Exp Med 196:1575, 2002.

48. Vincent MS, Leslie DS, Gumperz JE, Xiong X, Grant EP, Brenner MB: CD1-dependent dendritic cell instruction. Nat Immunol 3:1163, 2002.

49. Mills KH: Regulatory T cells: friend or foe in immunity to infection? Nat Rev Immunol 4:841, 2004. 